\title{
ANALISIS DAYA SAING DAN DAMPAK KEBIJAKAN PEMERINTAH TERHADAP KOMODITAS KELAPA SAWIT RAKYAT
}

\author{
Tifany Zia Aznur \\ Budidaya Perkebunan, Sekolah Tinggi Ilmu Pertanian Agrobisnis Perkebunan, Medan \\ E-mail : tifanyzia@ stipap.ac.id
}

\begin{abstract}
Various policies are undertaken to support the increase of production and export volume of palm oil products. This study aims to analyze the competitiveness and impact of government policies on palm oil commodities in West Pasaman Regency. The research was conducted by survey method on 30 samples taken intentionally through multistage purposive sampling. The data is analyzed using Policy Analysis Matrix and sensitivity analysis. The results showed that the commodity of palm oil in Pasaman Barat Regency is competitive based on competitive advantage and comparative advantage both in the form of Fresh Fruit Bunches (FFB) and Crude Palm Oil (CPO). This is evidenced by the value of Privat Cost Ratio on FFB of 0.72 and CPO of 0,86; Domestic Resource Cost Ratio on FFB of 0.66 and CPO of 0,96; the value of private profit on FFB of 87 million rupiah and CPO of 35 billion rupiah; and social profit on FFB of 122 million rupiah and CPO of 11 billion rupiah. The impact of government policy indicated that government policies are disincentive to output, protective to tradable input, and indicated a subsidy to domestic factors. This is showed by Nominal Protection Coefficient Output on FFB of 0.82 and CPO of 0.89; Nominal Protection Coefficient Input on FFB of 0.50 and CPO of 1.00; Effective Protection Coefficient on FFB of 0.93 and CPO of 0.80; Protection Coefficient on FFB of 0.71 and CPO of 3.21; and Subsidy Ratio to Produce on FFB of -0.09 and CPO of 0.09 .
\end{abstract}

Keywords : competitiveness, policy analysis matrix, palm oil

DOI: http://dx.doi.org/10.29040/jap.v22i1.2034

\section{PENDAHULUAN}

Komoditas kelapa sawit mempunyai peran yang cukup strategis dalam Kelapa sawit merupakan tanaman perkebunan yang mengalami pertumbuhan produksi yang cukup pesat dibandingkan dengan tanaman perkebunan lainnya di Indonesia. Berdasarkan data Statistik Perkebunan Indonesia tentang Kelapa Sawit dari Direktorat Jenderal Perkebunan (2015), produksi kelapa sawit Indonesia sebesar 21,958 juta ton pada tahun 2010 dan menjadi 31, 284 juta ton pada tahun 2015. Sementara produksi komoditas tananaman lainnya seperti karet hanya mencapai 3,1 juta ton, kelapa 2,96 juta ton, tebu 2,63 juta ton, dan kopi 664,5 ribu ton.

Dari total kelapa sawit yang dihasilkan, menurut Direktorat Jenderal Perkebunan (2015), ekspor CPO pada tahun 2014 sebesar 93,9\%, sementara Crude Palm Kernel Oil (CPKO) hanya mencapai $0,06 \%$ dari total ekspor minyak sawit Indonesia. Pada tahun 2010, nilai ekspor CPO Indonesia ke dunia sebesar USD 13,4 miliar dan terus mengalami perkembangan yang signifikan pada tahun 2014 menjadi USD 22,89 miliar (Direktorat Jenderal Perkebunan, 2015).

Melihat situasi ini, berbagai kebijakan dan upaya untuk mendorong dan meningkatkan ekspor dilakukan pemerintah yang terutama ditujukan untuk meningkatkan penerimaan devisa negara dari hasil ekspor, mendorong perkembangan industri dalam negeri yang berorientasi ekspor, meningkatkan daya saing barang ekspor di pasaran internasional, meningkatkan penghasilan produsen di bidang ekspor, dan lain-lain yang bersangkutan dengan hal tersebut. (Kamaluddin, 2006: 123).

Pemerintah mengeluarkan kebijakan berupa penetapan harga patokan ekspor atas produk pertanian dan kehutanan yang dikenakan bea keluar sejak April 2010 melalui Peraturan Menteri Perdagangan Republik Indonesia Nomor 18/MDAG/PER/3/2017. Penetapan Harga Patokan Ekspor (HPE) ditetapkan berpedoman pada harga referensi yang ditetapkan berdasarkan harga rata-rata selama periodic terakhir sebelum penetapan Patokan Ekspor 
(HPE). Adapun tarif Bea Keluar untuk komoditi Kelapa Sawit, Crude Palm Oil (CPO) dan produk turunnanya berpedoman pada harga referensi yang didasarkan pada rata - rata tertimbang Cost Insurance Freight (CIF) Crude Palm Oil (CPO) dari Rotterdam, bursa Malaysia dan bursa Indonesia. Jika harga referensi lebih dari US\$750.00 -US\$ 800.00 perton, maka dikenakan tarif bea keluar sebesar US\$ 3 per ton (Kementrian Perdagangan Republik Indonesia, 2017)

Kabupaten Pasaman Barat memiliki potensi yang besar dalam pengembangan komoditas kelapa sawit karena didukung oleh letak geografis, keadaan iklim dan areal yang luas dan subur. Menurut Direktorat Jenderal Perkebunan, Kabupaten Pasaman Barat memiliki luas areal perkebunan sawit terbesar di Sumatera Barat dengan luas $163.438 \mathrm{Ha}$ dan produksi sawit terbesar dengan jumlah produksi sebesar 2.378.850,45 ton sehingga Kabupaten Pasaman Barat merupakan sentra pengembangan komoditas kelapa sawit di Sumatera Barat.

Saat ini, pemerintah Kabupaten Pasaman Barat melalui Dinas Perkebunan melakukan berbagai kebijakan terkait pengembangan komoditas perkebunan yang diekspor. Kebijakan pengembangan komoditas dimaksudkan untuk dapat meningkatkan daya saing komoditas melalui upaya peningkatan efisiensi, produktivitas usaha agribisnis komoditi perkebunan sehingga akan meningkatkan pendapatan petani dan mendorong penerimaan negara melalui devisa ekspor (Dinas Perkebunan Pasaman Barat, 2017:11).

Selain kebijakan penetapan harga patokan ekspor dan bea ekspor, pemerintah Kabupaten Pasaman Barat menerapkan kebijakan subsidi pupuk kepada petani kelapa sawit guna mendukung penigkatan produksi kelapa sawit rakyat. Kebijakan ini tertuang dalam Keputusan Kepala Dinas Kabupaten Pasaman Barat No. 188.4/06/DISBUN/I/2017 tentang Alokasi Pupuk Bersubsidi Sub Sektor Tanaman Perkebunan Tahun Anggaran 2017 pada Kecamatan, Kabupaten Pasaman Barat. Adapun jenis pupuk yang mendapatkan subsidi yaitu pupuk Urea, SP36, ZA, NPK/Phonska dan pupuk organik.

Oleh karena itu diperlukan suatu penelitian yang dapat memberikan gambaran tentang dayasaing kelapa sawit di Kabupaten Pasaman Barat. Dengan penelitian ini dapat diketahui bagaimana daya saing dari komoditas kelapa sawit di Kabupaten Pasaman Barat dengan membandingkan kelayakan usaha baik secara privat maupun secara sosial, serta efisiensi finansial dan ekonomi kelapa sawit.

Pendekatan yang sering digunakan untuk mengukur daya saing suatu komoditi adalah tingkat keuntungan yang dihasilkan dan efisiensi dalam pengusahaan komoditi tersebut. Keuntungan dapat dilihat dari dua sisi yaitu keuntungan privat dan keuntungan sosial. Sementara itu, efsiensi pengusahaan komoditi dapat dilihat dari dua indicator yaitu keungulan komparatif dan keunggulan kompetitif. Konsep daya saing yang menggunakan pendekatan keunggulan komparatif dan kompetitif digunakan untuk memberi masukan dalam perencanaan dan pengembangan usaha kelapa sawit.

Pendekatan daya saing sering dilakukan dengan menggunakan Matriks Analisis Kebijakan (Policy Analysis Matrix) PAM pada prinsipnya merupakan pendekatan sistem pembukuan "double entry" yang dapat digunakan untuk menganalisis berbagai pengaruh kebijakan pemerintah serta dampaknya terhadap sistem komoditi baik ditingkat petani, industri pengolahan maupun pemsaran. Hasil dari analisis PAM dapat menunjukkan dampak dari suatu kebijakan harga dan kebijakan faktor domestik, disamping itu juga dapat memberikan informasi dasar yang penting bagi Benefit Cost Analysis untuk mnegetahui kelayakan investasi suatu kegiatan pembangunan proyek pertanian (Pearson, Gotsch dan Bahri, 2004: 22).

Metode PAM dapat memberikan informasi dan analisis untuk membantu pengambil kebijakan pertanian dalam menelaah isu yang berkaitan dengan apakah sebuah sistem usahatani memiliki daya saing pada tingkat harga dan teknologi yang ada dan juga untuk mengetahui bagaimana dampak suatu investasi public terhadap tingkat efisiensi sistem usahatani (Pearson, Gotsch dan Bahri, 2004: 23). Setelah dilakukan analisis PAM maka dilakukan analisis sensitivitas yang bertujuan untuk melihat bagaimana hasil analisis suatu aktivitas ekonomi bila terjadi perubahan dalam perhitungan biaya atau manfaat.

Menurut Kadariah (1978) dalam Feryanto (2010:71), analisis sensitivitas dilakukan dengan cara: (1) mengubah besarnya variabel - variabel yang penting, masing - masing terpisah atau beberapa dalam kombinasi dengan suatu persentase dan menentukan seberapa besar kepekaan hasil perhitungan terhadap perubahan - perubahan tersebut, dan (2) menentukan tingkat perubahan yang membuat proyek tidak dapat diterima. Analisis sensitivitas membantu menentukan unsur - unsur kritikal yang berperan dalam menentukan hasil dan proyek. Analisis kepekaaan dilakukan dengan mengubah unsur atau kombinasi kemudian menentukan pengaruh dari perubahan tersebut terhadap hasil analisis. 
Penelitian ini bertujuan untuk menganalisis daya saing komoditas kelapa sawit di Kabupaten Pasaman Barat dan menganalisis dampak kebijakan pemerintah terhadap komoditas kelapa sawit di Kabupaten Pasaman Barat.

\section{METODE PENELITIAN}

\section{Tempat dan Waktu Penelitian}

Penelitian ini dilakukan di Kabupaten Pasaman Barat, Provinsi Sumatera Barat. Pemilihan lokasi ini dilakukan secara sengaja (purposive) dengan pertimbangan bahwa Kabupaten Pasaman Barat merupakan Kabupaten terluas yang mengusahakan kelapa sawit di Provinsi Sumatera Barat, dan kelapa sawit merupakan komoditas unggulan di Kabupaten Pasaman Barat. Penelitian dilaksanakan selama satu bulan dimulai pada tanggal 31 Oktober sampai pada 30 November 2017

\section{Metode Pengambilan Sampel}

Sampel yang digunakan dalam penelitian ini sebanyak 30 orang. Metode penarikan sampel yang digunakan pada penelitian ini adalah pengambilan sampel bertahap secara sengaja (multistage purposive sampling). Pengambilan sampel purposive dilakukan berdasarkan kriteria tertentu, yaitu berdasarkan umur tanaman, sampai mencukupi kebutuhan sampel yakni umur 1 sampai 23 tahun. Pengambilan sampel bertingkat ini biasanya digunakan bila ingin mengambil sampel dengan jumlah yang tidak banyak pada populasi yang besar. Berdasarkan sampling yang dilakukan, dipilih kecamatan dengan luas lahan kelapa sawit terluas, yaitu Kecamatan Kinali dan Kecamatan Sungai Aua. Dari masing - masing Kecamatan diambil sampel sebanyak 15 orang sehingga jumlah sampel genap berjumlah 30 orang.

\section{Jenis dan Sumber Data}

Data yang digunakan dalam penelitian ini adalah data primer dan data sekunder. Data primer dikumpulkan melalui metode survei dan wawancara dengan bantuan kuesioner yang meliputi faktor domestik (bibit, pupuk kandang, peralatan, tenaga kerja, lahan dan modal), input tradable (pupuk anorganik, herbisida), biaya - biaya (biaya handling pupuk, biaya transportasi pupuk, biaya transportasi pembelian TBS, biaya transportasi CPO, biaya handling CPO), prooduksi TBS dan CPO, serta nilai tukar dollar terhadap rupiah. Data sekunder adalah data pendukung yang diperoleh dari instansi terkait, lilteratur - literatur seperti jurnal ilmiah, modul, skripsi dan tesis yang berkaitan dengan topik penelitian.

\section{Metode Analisis Data}

Analisis data dilakukan secara kuantitatif meliputi analisis matrik kebijakan (Policy Analysis Matrix) dan analisis sensitivitas. Pemilihan metode PAM didasari pertimbangan bahwa analisis PAM juga dapat mengidentifikasi keunggulan kompetitif sekaligus keunggulan komparatif sebagai indikator dalam menentukan tingkat daya saing suatu komoditas sehingga tidak perlu melakukan dua kali perhitungan dan juga bisa menghitung dampak kebijakan pemerintah. Tabel PAM dapat dilihat pada tabel 1 berikut.

Tabel 1. Tabel Analisis Matriks Kebijakan

\begin{tabular}{lcccc}
\hline & Pendapatan & \multicolumn{2}{c}{ Biaya } & \multirow{2}{*}{ Keuntungan } \\
\cline { 3 - 4 } & & $\begin{array}{c}\text { Tradable } \\
\text { Input }\end{array}$ & $\begin{array}{c}\text { Faktor } \\
\text { Domestik }\end{array}$ & \\
\hline Harga Privat & $\mathrm{A}$ & $\mathrm{B}$ & $\mathrm{C}$ & $\mathrm{D}$ \\
\hline Harga Sosial & $\mathrm{E}$ & $\mathrm{F}$ & $\mathrm{G}$ & $\mathrm{H}$ \\
\hline Efek Divergensi & $\mathrm{I}$ & $\mathrm{J}$ & $\mathrm{K}$ & $\mathrm{L}$ \\
\hline
\end{tabular}

Baris pertama dari matrik PAM adalah perhitungan dengan harga privat yaitu harga aktual yang terjadi di pasar. Baris kedua merupakan perhitungan yang didasarkan pada harga sosial yaitu harga yang akan menghasilkan alokasi terbaik dari sumberdaya dan dengan sendirinya menghasilkan pendapatan tertinggi. Dan baris ketiga merupakan efek divergensi dihitung dengan menggunakan identitas divergensi. Menurut aturan perhitungan tersebut, semua nilai yang ada dibaris ketiga merupakan selisih antara baris pertama dengan baris kedua sebagai akibat dari dampak kebijakan. Dengan analisis matriks kebijakan dimungkinkan berbagai analisis keuntungan, analisis efisiensi finansial dan ekonomi, dan analisis dampak kebijakan pemerintah.

Tujuan pertama penelitian menggunakan baris pertama dan kedua dari matriks analisis kebijakan yakni analisis keuntungan. Usahatani kelapa sawit dikatakan mendapatkan keuntungan ketika keuntungan privat $\mathrm{D}=\mathrm{A}-(\mathrm{B}+\mathrm{C})>0$ dan keuntungan sosial $\mathrm{H}=\mathrm{E}-(\mathrm{F}+\mathrm{G})>0$. Selanjutnya untuk mengukur daya saing menggunakan 
keunggulan kompetitif dan keunggulan komparatif. Keunggulan kompetitif dapat dilihat dari nilai Rasio Biaya Privat (private cost ratio atau PCR) dan keunggulan komparatif dilihat dari nilai Rasio Biaya Sumberdaya Domestik (Domestic Resource Cost Ratio atau DRCR). Sistem produksi usahatani kelapa sawit memiliki keuntungan kompetitif ketika PCR = $\mathrm{C} /(\mathrm{A}-\mathrm{B})<1$ dan memiliki keunggulan komparatif ketika DRCR $=\mathrm{G} /(\mathrm{E}-\mathrm{F})<1$.

Sedangkan untuk tujuan kedua penelitian menggunakan analisis dampak kebijakan pemerintah menggunakan baris ketiga dari matriks analisis kebijakan dan analisis sensitivitas. Dampak kebijakan pemerintah dilihat dari tiga indikator yaitu, dampak kebijakan ouput, dampak kebijakan input, dampak kebijakan input dan output. Kebijakan pemerintah terhadap output dijelaskan oleh nilai Transfer Output (TO) I = A - E. dan koefisien proteksi Output Nominal (Nominal Protection Coefficient on Output) atau NPCO = A/E. Dampak kebijakan pemerintah terhadap input tradable dijelaskan dengan Transfer input (TI) $\mathrm{J}=\mathrm{B}$ $-\mathrm{F}$ dan Koefisien proteksi Input Nominal $(\mathrm{NPCI})=$ B /F sedangkan dampak kebijakan input domestik dijelaskan oleh transfer faktor (TF) $\mathrm{K}=\mathrm{C}-\mathrm{G}$. Kemudian dampak kebijakan input - output dijelaskan melalui analisis Koefisien. Proteksi Efektif (Effective Protection Coefficient) atau EPC = $(\mathrm{A}-\mathrm{B}) /(\mathrm{E}-\mathrm{F})$, Transfer Bersih (Net Transfer) atau $\mathrm{NT}=\mathrm{L}=\mathrm{D}-\mathrm{H}=\mathrm{I}-(\mathrm{J}+\mathrm{K})$, Koefisien Keuntungan (Provitability Coefficient) atau PC $=\mathrm{D}$
/ H dan Rasio Subsidi Bagi Produsen (Subsidi Ratio to Producers) atau SRP = L /E.

Analisis sensitivitas dilakukan berdasarkan perubahan - perubahan yang terjadi di lokasi penelitian. Skenario yang digunakan dalam analisis sensitivitas adalah sebagai berikut : (1) Analisis sensitivitas jika terjadi penurunan harga output dan faktor lain dianggap tetap (cateris paribus), (2) Analisis sensitivitas jika nilai tukar rupiah terhadap dollar Amerika melemah dan faktor lain dianggap tetap (cateris paribus), dan (3) Analisis sensitivitas jika terjadi perubahan harga pupuk (harga pupuk Urea, SP36, ZA, NPK jika tidak disubsidi oleh pemerintah) dan faktor lain dianggap tetap (cateris paribus).

\section{HASIL DAN PEMBAHASAN}

\subsection{Hasil Penelitian \\ Karakeristik Responden}

Petani yang menjadi responden (sumber informasi) adalah petani dalam satu rumah tangga yang tercatat sebagai anggota kelompok tani perkebunan di Kabupaten Pasaman Barat. Responden mempunyai kisaran umur 20 - 61 tahun atau rata-rata 43,7 tahun, pengalaman petani dalam berusahatani 2 - 23 tahun atau rata-rata pengalaman petani 12,6 tahun, jumlah tanggungan berkisar antara $1-6$ orang atau rata-rata tanggungan petani berjumlah 3 orang. Karakteristik responden yang menjadi sumber infromasi dapat dilihat pada Tabel 2 berikut.

Tabel 2. Karakteristik Responden Usahatani Kelapa Sawit Rakyat

\begin{tabular}{llcc}
\hline No & \multicolumn{1}{c}{ Karakteristik Responden } & Jumlah (Orang) & Persentase (\%) \\
\hline 1 & Berdasarkan Jenis Kelamin & & \\
& a. Laki-laki & 21 & 70 \\
& b. Perempuan & 9 & 30 \\
\hline 2 & Berdasarkan Umur & & \\
& a. Produktif (15-59 tahun) & 26 & 86,67 \\
& b. Tidak Produktif (> 59 tahun) & 4 & 13,33 \\
\hline 3 & Berdasarkan Pendidikan Formal & & \\
& a. SD & 7 & 23,33 \\
& b. SMP & 3 & 10 \\
& c. SMA & 17 & 56,67 \\
& d. AK & - & - \\
& e. S1 & 3 & 10 \\
\hline 4 & Berdasarkan Pengalaman Usahatani & & \\
& a. $\quad 10$ tahun & 11 & 36,67 \\
& b. $10-30$ tahun & 19 & 63,33 \\
& c. $>30$ tahun & - & - \\
\hline 5 & Berdasarkan Jumlah Tanggungan & & 13,33 \\
& a. $\quad 0$ & 4 & 70 \\
b. $1-5$ & 21 & 16,67 \\
\hline
\end{tabular}


Dari Tabel 2 terlihat bahwa berdasarkan jenis kelamin perbandingan petani yang menjadi responden sebanyak $70 \%$ atau 21 orang responden laki-laki dan 9 orang (30\%). petani lakilakimempunyai jam kerja yang lebih banyak daripada petani perempuan. Petani laki-laki bekerja sebanyak 8 jam/hari yang dinyatakan dalam 1 HKP (Hari Kerja Pria), sedangkan petani perempuan hanya bekerja sebanyak $0,7 \mathrm{HKP}$ atau rata-rata 5,6 jam.

Selanjutnya, umur merupakan salah satu faktor yang mempengaruhi tingkat kemampuan petani dalam pengelolaan usahataninya. Umur pada batas tertentu akan berpengaruh terhadap produktivitas kerja. Sebagian besar responden berada pada kisaran umur produktif $(86,67 \%)$, yaitu umur 15- 59 tahun, sehingga diharapkan produktivitas kerja masih relatif tinggi. Responden yang berada di kisaran umur non produktif hanya $13,33 \%$. Hal ini berarti usia produktif yang mendominasi responden.

Dari tingkat pendidikan formal pada Tabel 7 , terlihat bahwa sebagian besar respoden tergolong berpendidikan cukup tinggi yakni 56,67\% merupakan tamatan SMA. Sedangkan responden yang berpendidikan tinggi sampai jenjang sarjana hanya $10 \%$.. Pendidikan formal akan mempengaruhi kemampuan dan kecepatan menerima informasi dan inovasi baru.

Pengalaman petani dalam menjalankan usahataninya merupakan salah satu faktor yang dapat mempengaruhi keberhasilannya. Semakin lama petani bekerja pada kegiatan tersebut semakin banyak pengalaman yang diperoleh berkaitan dengan usahataninya. Dari Tabel 2 terlihat bahwa pengalaman petani responden terbanyak antara 1030 tahun $(63,33 \%)$. Hanya 36,67\% responden yang memiliki pengalaman dibawah 10 tahun. Pengalaman berusahatani tersebut cukup memadai dan dapat sebagai penunjang dalam pengembangan komoditi kelapa sawit.

Jumlah tanggungan keluarga responden dalam hal ini adalah tanggungan rumah tangga yang terdiri dari isteri, anak dan anggota keluarga lainnya yang menjadi tanggungan rumah tangga responden. Dari Tabel 2 terlihat bahwa responden yang memiliki tanggungan yang tergolong banyak yakni $1-5$ orang berjumlah $70 \%$, sedangkan hanya $13,33 \%$ tidak mempunyai tanggungan dan $16,67 \%$ memiliki tanggungan lebih dari lima orang.

\subsection{Pembahasan \\ Analisis Daya Saing Kelapa Sawit (TBS)}

Analisis daya saing komoditas kelapa sawit di Kabupaten Pasaman Barat dikur melalui analisis keuntungan dan analisis efisiensi dengan menggunakan analisis matriks kebijakan (Policy Analysis Matrix) yang disusun berdasarkan data penerimaan dan biaya produksi yang terbagi dalam dua kategori yaitu harga privat (analisis finansial) dan harga sosial (analisis ekonomi) selama 23 tahun dengan discount rate sebesar 7\%. Proses diskonto dilakukan untuk menentukan nilai NPV (Net Present Value) dari usahatani kelapa sawit. Perhitungan uraian harga privat dan harga sosial dapat dilihat pada Lampiran 23,24, 25 dan 26. Selanjutnya data yang diperoleh akan digunakan untuk menghitung nilai-nilai yang menjadi indikator dayasaing dan dampak kebijakan pemerintah terhadap dayasaing kelapa sawit di Kabupaten Pasaman Barat. Perhitungan analisis daya saing dilakukan pada level usahatani untuk mengetahui daya saing TBS dari kebun kelapa sawit rakyat dan juga pada level agroindustri untuk mengetahui daya saing CPO sawit rakyat.

Hasil analisis berdasarkan perhitungan PAM untuk TBS sawit rakyat dapat dilihat pada Tabel 3 berikut.

Tabel 3. Policy Analysis Matrix (PAM) TBS Sawit Rakyat

\begin{tabular}{|c|c|c|c|c|}
\hline & \multirow{2}{*}{$\begin{array}{c}\text { Penerimaan } \\
\text { Output (Revenue) }\end{array}$} & \multicolumn{2}{|c|}{ Input } & \multirow{2}{*}{ Keuntungan } \\
\hline & & Input Tradable & Faktor Domestik & \\
\hline Privat & $327.924 .502,30$ & $18.840 .950,43$ & $221.828 .149,60$ & $87.255 .402,27$ \\
\hline Sosial & $398.366 .991,81$ & $37.656 .419,55$ & $237.852 .212,44$ & $122.858 .359,82$ \\
\hline $\begin{array}{c}\text { Dampak } \\
\text { Divergensi }\end{array}$ & $(70.442 .489,50)$ & $(18.815 .469,11)$ & $(16.024 .062,83)$ & $(35.602 .957,55)$ \\
\hline PCR $=0,72$ & DRCR $=0,66 \quad \mathrm{NPC}$ & $0,82 \quad$ NPCI $=0,50$ & $\mathrm{EPC}=0,93 \quad \mathrm{PC}$ & 71 SRP $=-0,09$ \\
\hline
\end{tabular}


Dari Tabel 3 diatas terlihat bahwa keuntungan privat TBS kelapa sawit pada petani rakyat bernilai positif yakni sebesar Rp 87.255.402,27 dengan penerimaan privat sebesar $\mathrm{Rp}$ 327.924.502,3; biaya input tradabel sebesar $\mathrm{Rp}$ 18.840.950,43; dan biaya faktor domestik sebesar Rp 221.828.149,6. Hal ini berarti bahwa TBS sawit rakyat memiliki dayasaing yang tinggi pada tingkat harga dan teknologi yang ada sekarang. Keuntungan sosial TBS sawit rakyat juga bernilai yang positif yakni sebesar $\mathrm{Rp}$ 122.858.359,82 dengan penerimaan sosial sebesar Rp 398.366.991,81; biaya input tradabel sebesar $\mathrm{Rp} 37.656 .419,55$ dan biaya faktor domestik pada harga sosial sebesar $\mathrm{Rp}$ 237.852.212,44. Hal ini berarti bahwa pengusahaan perkebunan kelapa sawit rakyat memiliki efisiensi yang baik pada tingkat harga dan teknologi yang ada sekarang.

Berdasarkan Tabel 3 dapat diketahui bahwa dampak divergensi yang dihasilkan dari analisis PAM untuk penerimaan bernilai negatif, dampak divergensi untuk input tradabel dan faktor domestik bernilai negatif, dan juga dampak divergensi keuntungan bernilai negatif. Dampak divergensi penerimaan sebesar Rp (70.442.489,50), dampak divegensi keuntungan sebesar Rp $(35.602 .957,55)$. Dampak divergensi input tradabel bernilai negatif yakni sebesar $\mathrm{Rp}(18.815 .469,11)$ dan dampak divergensi faktor domestik sebesar $\mathrm{Rp}$ 16.024.062,83. Salah satu penyebab terjadinya divergensi adalah kegagalan pasar (market failure). Pasar dikatakan gagal jika tidak mampu menciptakan harga yang kompetitif yang menciptakan alokasi sumberdaya maupun produk yang efisien. Penyebab kedua dari timbulnya divergensi adalah kebijakan pemerintah yang disortif yaitu diterapkan untuk mencapai tujuan yang bersifat non-efisiensi (Pearson, 2005: 29).

Dari hasil PAM diperoleh nilai Rasio Biaya Privat (Private Cost Ratio/PCR) pada kebun kelapa sawit rakyat sebesar 0,72 . Jika nilai PCR $<1$, maka artinya sistem produksi usahatani kelapa sawit di level usahatani semakin kompetitif dan mampu membiayai faktor domestiknya pada harga privat dan kemampuannya tersebut akan meningkat. Nilai PCR sebesar 0,72 artinya untuk meningkatkan nilai tambah output TBS sebesar satu satuan diperlukan tambahan biaya faktor domestik lebih kecil dari satu satuan, yaitu sebesar 0,72 .

Nilai Rasio Biaya Sumberdaya Domestik (Domestic Resource Cost Ratio/DRCR) pada kebun kelapa sawit rakyat sebesar 0,66. Nilai DRCR $<1$ menunjukkan bahwa sistem produksi kelapa sawit di level usahatani efisien secara ekonomi dan mempunyai keunggulan komparatif. Nilai DRCR = 0,66 artinya untuk memproduksi atau menambah nilai tambah output TBS sebesar satu satuan dibutuhkan tambahan sumberdaya domestik sebesar 0,66 . Dengan kata lain, biaya produksi (input tradable dan faktor domestik) yang dikeluarkan petani lebih besar. Hal ini menunjukkan bahwa usaha memproduksi komoditas kelapa sawit di dalam negeri mampu memenuhi permintaan agroindustri kelapa sawit dalam negeri.

Nilai $\mathrm{NPCO}=0,82(\mathrm{NPCO}<1)$ menunjukkan bahwa kebijakan pemerintah ternyata bersifat disinsentif terhadap output. Nilai NPCI kebun sawit rakyat sebesar 0,50 (NPCI < 1) mengindikasikan bahwa ada kebijakan pemerintah yang bersifat protektif terhadap input tradabel. Dengan kata lain petani sawit rakyat telah menikmati kebijakan proteksi input tradabel dari pemerintah. Bila NPCI lebih kecil dari satu, harga domestik lebih rendah dari harga dunia, dan sistem seolah - olah disubsidi oleh kebijakan yang ada (Pearson, 2005: 78).

Nilai EPC menggambarkan arah kebijakan pemerintah bersifat melindungi atau menghambat produksi domestik secara efektif. Nilai EPC untuk TBS sebesar 0,93 (EPC $\leq 1)$ artinya kebijakan tidak bersifat protektif, tidak ada proteksi pemerintah terhadap komoditas domestik tersebut, baik terhadap TBS maupun CPO. Nilai Koefisien Keuntungan (PC) TBS sebesar 0,71 . Nilai $\mathrm{PC} \leq 1$ artinya keseluruhan kebijakan pemerintah tidak memberikan insentif kepada produsen. Nilai Rasio Subsidi Bagi Produsen (SRP) kebun kelapa sawit rakyat sebesar 0,09 (SRP < 0) artinya kebijakan pemerintah yang berlaku selama ini menyebabkan produsen mengeluarkan biaya produksi lebih besar dari biaya imbangan untuk berproduksi (Nurmalina 2010 dalam Tanjung 2017:90). Hal ini mengandung arti bahwa dengan kebijakan yang ada, petani membayar biaya produksi yang lebih tinggi dari opportunity cost berproduksi.

\section{Analisis Daya Saing Crude Palm Oil (CPO)}

Hasil analisis berdasarkan perhitungan PAM untuk CPO sawit rakyat dapat dilihat pada Tabel 4 berikut. 
Jurnal Akuntansi dan Pajak, 22(01), 2021, 75

Tabel 4. Policy Analysis Matrix (PAM) Pengolahan CPO Sawit Rakyat

\begin{tabular}{|c|c|c|c|c|}
\hline & \multirow{2}{*}{$\begin{array}{l}\text { Penerimaan Output } \\
\text { (Revenue) }\end{array}$} & \multicolumn{2}{|c|}{ Input } & \multirow{2}{*}{ Keuntungan } \\
\hline & & Input Tradable & Faktor Domestik & \\
\hline Privat & $253.044 .337 .167,05$ & $334.018 .885,5$ & $217.233 .665 .662,54$ & $35.476 .652 .619,00$ \\
\hline Sosial & $283.527 .240 .363,47$ & $334.018 .885,5$ & $272.155 .073 .395,78$ & $11.038 .148 .082,19$ \\
\hline $\begin{array}{c}\text { Dampak } \\
\text { Divergensi }\end{array}$ & $(30.482 .903 .196,42)$ & - & $(54.921 .407 .733,24)$ & $24.438 .504 .536,82$ \\
\hline PCR $=0,86$ & 6 DRCR $=0,96 \mathrm{~N}$ & $\mathrm{O}=\mathbf{0 , 8 9} \quad \mathrm{NPCI}$ & $00 \quad E P C=0,80 \quad P C$ & 21 SRP = 0,09 \\
\hline
\end{tabular}

Dari Tabel 4 diatas terlihat bahwa keuntungan privat CPO pada pabrik pengolahan bernilai positif yakni sebesar $\mathrm{Rp} 35.476 .652 .619,00$ dengan penerimaan privat sebesar $\mathrm{Rp}$ 253.044.337.167,05; biaya input tradabel sebesar $\mathrm{Rp}$ 334.018.885,5; dan biaya faktor domestik sebesar Rp 217.233.665.662,54. Hal ini berarti bahwa CPO sawit rakyat memiliki dayasaing yang tinggi pada tingkat harga dan teknologi yang ada sekarang. Keuntungan sosial TBS sawit rakyat juga bernilai yang positif yakni sebesar Rp 11.038.148.082,19 dengan penerimaan sosial sebesar $\mathrm{Rp}$ 283.527.240.363,47; biaya input tradabel sebesar $\mathrm{Rp}$ 334.018.885,5 dan biaya faktor domestik pada harga sosial sebesar Rp 272.155.073.395,78. Hal ini berarti bahwa pengusahaan pengolahan CPO dari kelapa sawit rakyat memiliki efisiensi yang baik pada tingkat harga dan teknologi yang ada sekarang.

Berdasarkan Tabel 4 dapat diketahui bahwa dampak divergensi yang dihasilkan dari analisis PAM untuk penerimaan bernilai negatif, dampak divergensi untuk input tradabel bernila nol, dampak divergensi faktor domestik bernilai negatif, dan dampak divergensi keuntungan bernilai positif. Dampak divergensi penerimaan sebesar $\mathrm{Rp}$ (30.482.903.196,42), dampak divegensi keuntungan sebesar Rp 24.438.504.536,82. Dampak divergensi input tradabel bernilai nol dan dampak divergensi faktor domestik sebesar Rp $(54.921 .407 .733,24)$.

Nilai Rasio Biaya Privat (Private Cost Ratio/PCR) pada pengolahan CPO sebesar 0,86 . Nilai PCR 0,86 artinya untuk meningkatkan nilai tambah output CPO sebesar satu satuan diperlukan tambahan biaya faktor domestik lebih kecil dari satu satuan, yaitu sebesar 0,86. Nilai tersebut juga menunjukkan CPO sawit rakyat pada kondisi kebijakan yang ada ternyata telah efisien secara finansial atau dengan kata lain memiliki keunggulan kompetitif.

Nilai Rasio Biaya Sumberdaya Domestik (Domestic Resource Cost Ratio/DRCR) pada pabrik kelapa sawit sebesar 0,96. nilai DRCR $=0,96$ artinya untuk untuk memproduksi atau menambah nilai tambah output CPO sebesar satu satuan dibutuhkan tambahan sumberdaya domestik sebesar 0,96. Dengan kata lain, apabila CPO diproduksi di dalam negeri maka membutuhkan biaya sebesar 0,96 sehingga terjadi penghematan biaya sebesar 0,04 satuan. Jika memproduksi CPO di dalam negeri akan lebih murah dibandingkan dengan mengimpor CPO dari negara lain sehingga CPO Kabupaten Pasaman Barat berdaya saing karena memiliki keunggulan komparatif. Untuk memproduksi CPO di Kabupaten Pasaman Barat hanya membutuhkan biaya sumberdaya domestik sebesar $96 \%$ terhadap baiya impor yang dibutuhkan. Hal ini mengandung arti bahwa setiap US\$ 1 yang dibutuhkan untuk impor $\mathrm{CPO}$, jika diproduksi di Pasaman Barat hanya membutuhkan US\$ 0,96.

Nilai $\mathrm{NPCO}=0,89(\mathrm{NPCO}<1)$ menunjukkan bahwa kebijakan pemerintah ternyata bersifat disinsentif terhadap output. Nilai transfer output ternyata juga negatif yang menunjukkan produsen dan konsumen telah menerima dan membayar harga yang lebih rendah dari harga aktual. Nilai NPCI pengolahan CPO bernilai satu. NPCI $=1$ mengindikasikan bahwa biaya input domestik lebih mahal dari biaya input pada tingkat harga dunia, dengan kata lain tidak ada kebijakan yang bersifakt protektif terhadap input dalam pengolahan CPO sawit rakyat dan tidak ada pula kebijakan subsidi terhadap input tradable yang digunakan.

Nilai EPC pada CPO sebesar 0,80. Nilai EPC menggambarkan arah kebijakan pemerintah bersifat melindungi atau menghambat produksi domestik secara efektif. Nilai EPC $\leq 1$ artinya kebijakan tidak bersifat protektif, tidak ada proteksi pemerintah terhadap komoditas domestik tersebut, baik terhadap TBS maupun CPO. Nilai Koefisien Keuntungan (PC) CPO sebesar 3,21. Nilai PC > 1 menjukkan bahwa secara keseluruhan kebijakan pemerintah yang ada memberikan insentif kepada produsen. Nilai Rasio Subsidi Bagi Produsen (SRP) pada pabrik kelapa sawit sebesar 0,09 . nilai $S R P \geq 0$ artinya kebijakan pemerintah yang berlaku selama ini tidak menyebabkan produsen mengeluarkan biaya produksi lebih besar dari biaya imbangan 
untuk berproduksi. Hal sebaliknya justru terjadi pada pengolahan kelapa sawit. Kebijakan pemerintah justru telah mengakibatkan pada CPO harus membayar biaya produksi yang lebih tinggi dari opportunity cost berproduksi.

\section{Analisis Sensitivitas}

Skenario yang digunakan dalam analisis sensitivitas dalam penelitian ini adalah (1) Analisis sensitivitas jika terjadi penurunan harga output CPO dan faktor lain dianggap tetap, (2) Analisis sensitivitas jika nilai tukar rupiah terhadap dollar Amerika Serikat (US\$) melemah dan faktor lain dianggap tetap, dan (3) Analisis sensitivitas jika terjadi perubahan harga pupuk (harga pupuk Urea, SP36, ZA, NPK jika tidak disubsidi oleh pemerintah) dan faktor lain dianggap tetap (cateris paribus).

Adapun perubahan harga CPO sebesar $6 \%$ ditetapkan berdasarkan fluktuasi harga dalam 2 tahun yaitu November 2016 - Oktober 2018. Data yang digunakan untuk tahun 2018 merupakan proyeksi dari data harga CPO pada Januari 2018, yakni sebesar US\$ 697,34. Berdasarkan hasil analisis dapat diketahui bahwa menurunnya harga aktual output CPO memberikan penerimaan privat sebesar Rp. 237.861.676.937,02 sedangkan pada keuntungan privat Rp 20.293.992.388,98. Skenario sensitivitas turunnya harga output sebesar 6\% menyebabkan menurunnya penerimaan dari CPO. Nilai besarnya penurunan penerimaan yaitu $6 \%$ dari penerimaan privat pada kondisi normal, dan penurunan keuntungan sebanyak 42,8\%. Dari hal tersebut bisa dilihat bahwa harga jual CPO sangat sensitif terhadap perubahan harga. Artinya setiap perubahan $1 \%$ harga menyebabkan penurunan keuntungan juga sebesar 7,13\%. Hal ini menunjukkan bahwa penurunan harga jual CPO berbanding lurus dengan penurunan penerimaan dan keuntungan CPO. Kemudian nilai transfer output atau dampak divergensi juga mengalami penurunan sebesar $\quad 15.182 .660 .230 \quad$ menjadi (45.665.563.426,45).

Skenario perubahan nilai mata uang didasarkan pada perkembangan nilai mata uang rupiah terhadap dollar pada tahun November 2016 Oktober 2017 sebesar 0,07\%, cateris paribus. Perubahan nilai mata uang hanya berpengaruh terhadap harga sosial output CPO dan harga sosial input tradable. Berdasarkan hasil analisis diketahui bahwa keuntungan sosial yang diterima oleh petani sebesar Rp 121.819.665,10. Skenario sensitivitas melemahnya nilai tukar rupiah terhadap dollar sebesar 0,07\% menyebabkan menurunnya tingkat keuntungan sosial yang diterima petani sebesar $1 \%$ dari keuntungan sosial pada kondisi normal. Akan tetapi Rasio DRCR dan nilai transfer output (dampak divergensi) tidak mengalami perubahan, artinya perubahan nilai tukar sebesar $0,07 \%$ tidak berpengaruh terhadap daya saing TBS.

Kemudian melemahnya nilai tukar rupiah terhadap dollar juga berpengaruh terhadap harga sosial CPO. Dari hasil analisis diketahui bahwa penerimaan sosial CPO yang diterima sebesar Rp 301.937.526.465,62 dan keuntungan sosial sebesar $\mathrm{Rp} \quad 29.448 .434 .184,33$. Skenario sensitivitas melemahnya nilai tukar rupiah terhadap dollar sebesar $0,07 \%$ menyebabkan meningkatnya tingkat penerimaan sosial. Hal ini disebabkan karena nilai harga jual CPO yang semakin meningkat sehingga harga CPO menjadi semakin mahal. Skenario sensitivitas melemahnya nilai tukar rupiah terhadap dollar sebesar 0,07\% menyebabkan meningkatnya tingkat penerimaan sosial sebesar $7 \%$ dan keuntungan sosial sebesar 166,79\%, meningkatnya transfer output sebesar $60,4 \%$ dan menurunnya transfer bersih sebesar 75,33\%.

Selanjutnya skenario jika harga pupuk anorganik seperti pupuk Urea, SP36, ZA, NPK jika tidak disubsidi oleh pemerintah, maka akan berpengaraguh terhadap biaya input tradabel dalam usahatani. Skenario jika pupuk anorganik yang digunakan petani dalam berusahatani tidak disubsidi oleh pemerintah, maka menyebabkan terjadinya peningkatan biaya input tradabel sebesar $138 \%$ dari biaya input tradabel yang harus dikeluarkan pada saat adanya kebijakan subidi. Hal ni mengakibatkan tejadinya penurunan penerimaan privat TBS sebesar 29,78\%. Akan tetapi perubahan ini masih memberikan tingkat keuntungan bagi petani. Adapun nilai PCR meningkat menjadi 0,78 dari sebelumnya 0,72 . Nilai PCR $<1$ menunjukkan bahwa TBS masih memiliki keunggulan kompetitif walaupun kebijakan subsidi tidak diberlakukan oleh pemerintah. Karena harga input tradabel tidak disusidi pemerintah, makan nilai transfer input mengalami peningkatan dan bernilai positif, hal ini terjadi karena biaya input tradabel pada komponen privat lebih besar daripada biaya input tradabel sosialnya. Sehingga, nilai transfer input mengalami peningkatan sebesar 138,11\% menjadi 7.171.033,41.

\section{KESIMPULAN}

Komoditas kelapa sawit rakyat di Kabupaten Pasaman Barat memiliki daya saing secara finansial dan ekonomi pada saat berbentuk TBS maupun dalam bentuk CPO. Komoditas sawit rakyat di Kabupaten Pasaman Barat juga memiliki 
keunggulan kompetitif dan keunggulan komparatif dalam bentuk TBS dan CPO. Hal ini ditunjukkan dengan nilai keuntungan privat (PP) dan keuntungan sosial (SP) TBS dan CPO yang bernilai positif Kemudian nilai Rasio Biaya Privat CPO kecil dari satu dan dan nilai Rasio Biaya Sumberdaya Domestik TBS kecil dari satu.

Kebijakan pemerintah yang diterapkan pada input maupun output memberikan dampak terhadap komoditas kelapa sawit di Pasaman Barat. Analisis dampak kebijakan pemerintah terhadap output menunjukkan bahwa kebijakan pemerintah bersifat disinsentif pada output, sedangkan kebijakan pemerintah pada input menunjukkan adanya kebijakan subsidi. Analisis dampak kebijakan pada input mengindikasikan adanya kebijakan pemerintah yang bersifat protektif terhadap input tradabel dan adanya subsidi pemerintah terhadap faktor domestik. Analisis dampak kebijakan input-output pada usahatani menunjukkan kebijakan untuk melindungi produksi tidak berjalan dengan baik. Secara keseluruhan kebijakan pemerintah memberikan insentif kepada produsen dikarenakan petani membayar biaya produksi yang lebih rendah dari opportunity cost berproduksi.

\section{Implikasi Kebijakan}

CPO sawit rakyat memiliki daya saing yang rendah. Hal ini disebabkan karena produksi TBS yang dihasilkan dari petani masih rendah sehingga rendemen CPO sawit rakyat kecil. Untuk mencapai tujuan tersebut pemerintah daerah Kabupaten Pasaman Barat dapat memberikan dukungan dalam peningkatan produksi kelapa sawit rakyat melalui penyediaan (subsidi) bibit unggul yang bersertifikat, selain itu peran penyuluh pertanian khususnya perkebunan kelapa sawit dapat dioptimalkan dalam menuju produktivitas kelapa sawit yang meningkat seperti pengawasan dan penyuluhan dalam pemeliharaan kelapa sawit terkait pemberian pupuk dan juga pentingnya melakukan pemangkasan serta memanen buah sesuai dengan standar kematangan panen.

\section{REFERENSI}

Dinas Perkebunan Pasaman Barat. 2017. Data Statistik Komoditi Perkebunan Tahun 2016. 20 hal

Feriyanto, Andri. 2015. Perdagangan Internasional: Kupas Tuntas Prosedur Ekspor Impor, Jakarta: Mediatera.
Feryanto. 2010. Analisis Daya Saing dan Dampak Kebijakan Pemerintah terhadap Komoditas Susu Sapi Lokal di Jawa Barat [Tesis] Bogor. Sekolah Pascasarjana Institut Pertanian Bogor. 188 hal

Kamaluddin, Rustian. 2006. Beberapa Aspek Pembangunan Perekonomian Daerah dan Hubungan Ekonomi Keuangan Luar Negeri. Jakarta : Penerbit Universitas Trisakti. 278 hal

Kementrian Perdagangan Republik Indonesia. 2017. Dokumen Peraturan Menteri Perdagangan RI. No. 18/M-DAG/PER/3/2-17 tentang Penetapaan Harga Patokan Ekspor atas Produk Pertanian dan Kehutanan yang Dikenakan Bea Keluar. 62 hal

Pearson, Scott; Carl Gotsch; dan Sjaiful Bahri. 2005. Aplikasi Policy Analysis Matrix pada Pertanian Indonesia. Jakarta: Yayasan Obor Indonesia. 397 hal

Tarigan, S. 2005. Perencanaan Pembangunan Wilayah. Bumi Aksara.

Utami, Ami Sukma; Nofialdi; Rini Hakimi; dan Dwi Evaliza. 2016. Pembangunan Perkebunan Kelapa Sawit Swadaya di Lahan Ulayat Minangkabau. Prosiding Lokakarya dan Seminar: Mencari Model Pemberdayaan dan Peremajaan Perkebunan untuk Sawit Indonesia yang Berkelanjutan. USU Press. 